UCRL-JC-129167

\title{
Major Repository Design Issues
}

\author{
J.A. Blink \\ J.N. Bailey

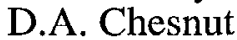 \\ J.R. Compton \\ R.D. Snell
}

This paper was prepared for submittal to the

\author{
American Nuclear Society \\ 1998 International High-Level Radioactive Waste Management Conference \\ Las Vegas, $N V$ \\ May 11-14, 1998
}

\section{March 1998}

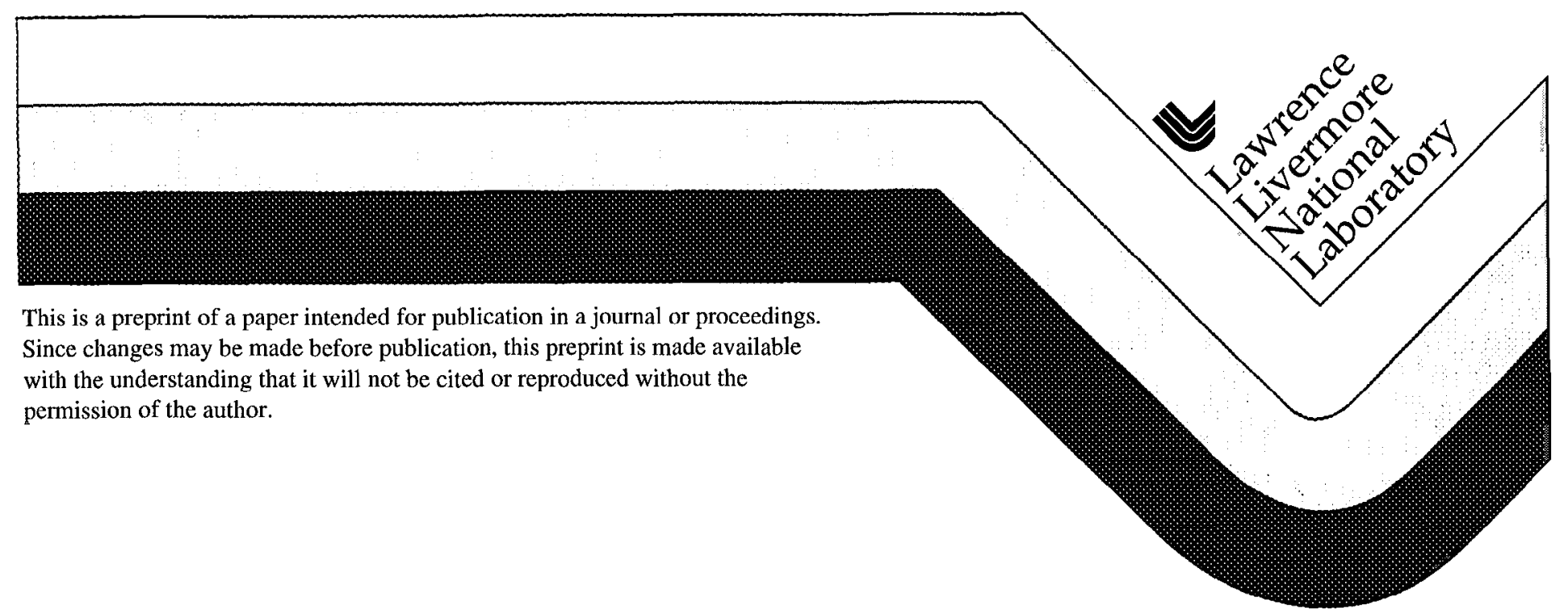




\section{DISCLAIMER}

This document was prepared as an account of work sponsored by an agency of the United States Government. Neither the United States Government nor the University of California nor any of their employees, makes any warranty, express or implied, or assumes any legal liability or responsibility for the accuracy, completeness, or usefulness of any information, apparatus, product, or process

disclosed, or represents that its use would not infringe privately owned rights. Reference herein to any specific commercial product, process, or service by trade name, trademark, manufacturer, or otherwise, does not necessarily constitute or imply its endorsement, recommendation, or favoring by the United States Government or the University of California. The views and opinions of authors expressed herein do not necessarily state or reflect those of the United States Government or the University of California, and shall not be used for advertising or product endorsement purposes. 


\title{
MAJOR REPOSITORY DESIGN ISSUES
}

\author{
James A. Blink, Lawrence Livermore National Laboratory (LLNL), \\ Civilian Radloactive Waste Management System \\ Management and Operating Contractor (CRWMS M\&O); \\ Jack N. Bailey, TRW, CRWMS M\&O; \\ Dwayne A. Chesnut, LLNL, CRWMS M\&O; \\ James R. Compton, U.S. Department of Energy; and \\ Richard D. Snell, Fluor Daniel Inc., CRWMS M\&O
}

\section{INTRODUCTION}

The Yucca Mountain Project is focused on producing a four-part viability assessment in late FY98. Its four components (design, performance assessment, cost estimate, and licensing development plan) must be consistent. As a tool to clarify design issues and compare design and performance assessment options, a series of repository sketches were developed for the sequential time phases of a repository. The boundaries of the time phases correspond to evolution in the engineered barrier system (EBS).

\section{WORK DESCRIPTION}

Using performance assessment calculations and engineering estimates, time phases were defined. For each time phase, the pertinent inputs to EBS performance were estimated. These parameters include degree of ventilation, waste package (WP) temperature and relative humldity, seepage into the drift, near-field saturation, and alteration of the hydrology of the ambient rock. In addition, for each time phase, the EBS performance measures were estimated; these include drift liner, drift wall, and invert integrity; WP corrosion allowance material (CAM) remaining thicknoss; WP crevice chemistry, WP corrosion resistant material (CRM) integrity, cladding integrity, waste form mobilization, and radionuclide transport out of the WF. For each phase, the appropriate EBS performance inputs and performance measures were used to define the physical situation (pictorially in the sketch) and were annotated on the sketches.

\section{RESULTS}

Ten time phases were defined for the reference design as it existed' in September 1997. This design is expected to meet the design constralnts summarized in the Controlled Design Assumptlons Document ${ }^{2}$. It should be noted that the recent improvement in CRM (from Alloy 625 to Alloy C-22) is expected to result in considerably longer WP lifetimes than shown in the sketches, with little change in the cost or operational constraints of the potential repository.

The ten phases are described below; the sketches will be dlsplayed on the poster.

1. WP emplacement (for a given WP) to Drift Closure (when the drift is full); several months

2. Drift Closure to Repository Closure (when the ramps and shafts are sealed); until 100 years after the first drift is closed

3. Repository Closure to 200 Years (drift liner still intact) 
4. $200-400$ Years (period of potential drift liner collapse)

5. 400-1,000 Years (period of initial drift wall collapse)

6. 1,000 - 3,000 Years (WP falls to boiling temperature at the beginning of the period and below boiling at the end of the period)

7. 3,000 - 10,000 Years (most WPs have at least one penetration through the CAM, $30 \%$ of WPs have at least one penetration through the CRM; potentially the end of the regulatory period)

8. 10,000 - 20,000 Years ( $50 \%$ of WPs breached; dose rate rising to its peak)

9. 20,000 - 100,000 Years (Return to ambient conditlons; no further WP failure; dose rate peaks and begins to decline)

10. $100,000-1,000,000$ Years (Extremely slow corrosion collapses the WPs)

For each time phase, the performance inputs and performance measures were estimated and used to construct the sketches and annotations.

\section{CONCLUSIONS AND DISCUSSION}

These sketches and the discussion of their assumptions have stimulated designers and performance analysts to consider new fallure modes (such as rock fall) and to modify analysis boundary conditions accordingly.

The present sketches use current "expected values" to define performance measures. Where there is a choice between depicting a failed component or an intact component (because the analysis predicts some fractlon have failed), the failed component is used in the sketch; hence the sketches tend toward the "worst case." A second set of sketches is being drawn to deplct the alternate situation.

A number of design options are being considered for the VA. These include ceramic coatings on the WP, backfill, and a drip shield. As the performance of these optlons is estimated, alternate skotches are being drawn to depict the physical conditions, assumptions, and performance measures. The result is an Increase in the transparency of both the design and the performance assessment.

\section{REFERENCES}

1. CRWMS Management and Operating Contractor, "Reference Design Description for a Geologlcal Repository, B00000000-01717-5707-00002, Rev. 1, November $25,1997$.

2. CRWMS Management and Operating Contractor, "Controlled Design Assumptions Document," Revision 04, ICN 03, Document Identifler B0000000001717-4600-00032, November, 1997.

*This work was performed under the auspices of the U.S. Department of Energy by Lawrence Livermore National Laboratory under contract No. W-7405-Eng-48. 


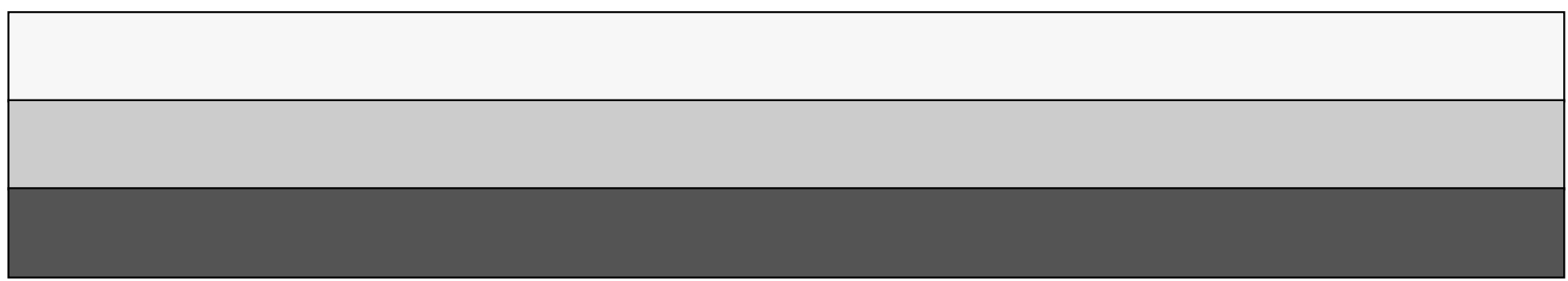

